\title{
Clinical outcome following DIAM implantation for symptomatic lumbar internal disk disruption: a 3-year retrospective analysis [Corrigendum]
}

Lu K, Liliang PC, Wang HK, Chen JS, Chen TY, Huang R, Chen HJ. J Pain Res. 2016;9:917-924.

Page 917, author affiliation list, the authors have requested for the affiliations to be listed as shown below.

\author{
Kang Lu' \\ Po-Chou Liliang' \\ Hao-Kuang Wang' \\ Jui-Sheng Chen' \\ Te-Yuan Chen' \\ Ruyi Huang ${ }^{2}$ \\ Han-Jung Chen ${ }^{1,3}$
}

'Department of Neurosurgery, E-Da Hospital, I-Shou University, ${ }^{2}$ Department of Family Medicine, E-Da Hospital, I-Shou University, ${ }^{3}$ Department of Neurosurgery, E-Da Cancer Hospital, College of Medicine, I-Shou University, Kaohsiung, Taiwan

\section{Journal of Pain Research}

\section{Publish your work in this journal}

The Journal of Pain Research is an international, peer reviewed, open access, online journal that welcomes laboratory and clinical findings in the fields of pain research and the prevention and managemen of pain. Original research, reviews, symposium reports, hypothesis formation and commentaries are all considered for publication.

\section{Dovepress}

The manuscript management system is completely online and includes a very quick and fair peer-review system, which is all easy to use. Visit http://www.dovepress.com/testimonials.php to read real quotes from published authors. 